\title{
Penggunaan Snake and Ladder Game untuk Meningkatkan Kemampuan Berbicara Bahasa Inggris Siswa SMPLB Banda Aceh
}

\author{
Mariah M. Junus \\ SMPLB Banda Aceh \\ mariah.smplb@gmail.com \\ DOI : 10.32672/jsa.v7i5.1512
}

\begin{abstract}
ABSTRAK
Penelitian ini dilaksanakan berdasarkan latar belakang berupa beberapa siswa jarang fokus dan kurang aktif dalam pembelajaran Bahasa Inggris serta kurang mengunakan Bahasa Inggris dalam menanyakan sesuatu.Sehingga beberapa siswa mendapatkan hasil belajar yang kurang memuaskan. Oleh karena itu, perlu dilaksanakan suatu pembelajaran yang dapat memberi kesempatan kepada siswa untuk melakukan kegiatan speaking dalam bahasa Inggris. Tujuan penelitian ini adalah untuk serta hasil belajar siswa kelas IX di SMPLB Banda Aceh dalam pembelajaran speaking dengan menggunakan media games. Dalam penelitian ini, peneliti menerapkan media games dalam pembelajaran bahasa Inggris dalam keterampilan berbicara di SMPLB Banda Aceh. Games dirancang untuk dapat memberi banyak kesempatan bagi siswa untuk melakukan kegiatan berbicara agar pembelajaran speaking dapa bermakna dan menyenangkan bagi siswa di sekolah.Subjek penelitian terdiri dari 11 siswa kelas IX di SMPLB Banda Aceh. Instrumen yang digunakan dalam penelitian ini adalah lembar observasi, catatan lapangan, rekaman video, serta dokumentasi. Kesimpulan hasil penelitian ini diantaranya, nilai rerata hasi belajar keterampilan speaking meningkat pada setiap siklusnya.Pada siklus I adalah 87, dan pada siklus II 91. Dengan demikian, media games dapat dijadikan salah satu upaya untuk meningkatkan keaktifan dan hasil belajar siswa dalam pembelajaran Bahasa Inggris di sekolah.
\end{abstract}

Kata Kunci: Kemampuan, Berbicara, dan Game

\section{PENDAHULUAN}

Bahasa adalah salah satu alat komunikasi untuk menyampaikan gagasan atau pendapat dan perasaan kepada orang lain. Melalui bahasa manusia dapat saling berhubungan (berkomunikasi), saling berbagi pengalaman, saling belajar dari yang lain, dan meningkatkan kemampuan intelektual. Dengan demikian setiap orang dituntut untuk terampil berbahasa. Bila setiap orang sudah terampil berbahasa, maka komunikasi antar sesama akan berlangsung dengan baik. Komunikasi yang dimaksud di sini adalah suatu proses penyampaian maksud pembicara kepada orang lain dengan menggunakan saluran tertentu. Maksud komunikasi dapat berupa pengungkapan pikiran, gagasan, ide, pendapat, persetujuan, keinginan, penyampaian informasi tentang suatu peristiwa, dan lain-lain. Pentingnya fungsi bahasa sebagai alat komunikasi dan alat berpikir terlihat juga pada pentingnya belajar bahasa Inggris. 
Mariah M. Yunus

Dalam mata pelajaran bahasa Inggris ada 4 keterampilan yang harus dikembangkan dalam setiap pembelajaran. Keempat skills ini yaitu listening, reading, speaking dan writting. Dengan demikian speaking merupakan salah satu keterampilan yang memang harus dikembangkan dalam pembelajaran bahasa Inggris. penjelasan tentang keterampilan speaking, Shastri (2010) menjelaskan bahwa dalam proses pemerolehan bahasa pertama, listening dan speaking datang secara natural. Harmer (2001: 269), Speaking adalah kemampuan berbicara yang melibatkan bukan hanya pengetahuan dalam unsur kebahasaan namun juga kemampuan untuk memproses informasi. Kemampuan berbahasa Inggris telah menjadi perhatian khusus dalam dunia pendidikan. Dimana peserta didik harus mampu berbahasa Inggris dengan baik secara lisan maupun tulisan. Kata mampu dalam berbahasa Inggris tidak hanya dalam berbicara atau menulis, akan tetapi peserta didik mampu untuk memahami dan dapat menangkap makna dari lawan bicara atau dalam sebuah tulisan/bacaan. Didalam hal ini, guru menjadi fasilitator yang dapat mengembangkan kemampuan peserta didik dalam bahasa Inggris. Guru diharapkan bisa memberikan metode atau media pembelajaran yang dapat membuat siswa aktif dalam keterampilan berbicara dan membuat pembelajaran bahasa Inggris menyenangkan.

Keterampilan berbicara merupakan inti dari proses pembelajaran bahasa di sekolah, karena dengan pembelajaran berbicara siswa dapat berkomunikasi di dalam maupun di luar kelas sesuai dengan perkembangan jiwanya (Galda dalam Supriyadi, 2005:34). Pembelajaran keterampilan berbicara penting diajarkan karena dengan keterampilan itu seorang siswa akan mampu mengembangkan kemampuan berpikir, membaca, menulis, dan menyimak. Kemampuan berpikir tersebut akan terlatih ketika mereka mengorganisasikan, mengkonsepkan, dan menyederhanakan pikiran, perasaan, dan ide kepada orang lain secara lisan.

Di dalam silabus kurikulum 2013 untuk kelas IX, siswa diharapkan dapat menyusun teks lisan dan tulis untuk menyatakan dan menanyakan tentang tindakan/kegiatan/kejadian yang sedang dilakukan/terjadi pada saat ini, waktu lampau, dan waktu yang akan datang, dengan memperhatikan fungsi sosial, struktur teks, dan unsur kebahasaan yang benar dan sesuai konteks. Dari silabus ini, dapat disimpulkan bahwa siswa diharapkan mampu untuk membuat dialog atau kalimat dalam bahasa Inggris sesuai dengan materi yang di ajarkan.

Selama dua bulan terakhir ini, peneliti telah mengajar di SMPLB Banda Aceh. Disini peneliti melihat beberapa kondisi dimana terlihat beberapa siswa jarang fokus dan aktif dalam pembelajaran Bahasa Inggris serta kurang mengunakan bahasa Inggris dalam menanyakan sesuatu. Oleh sebab itu, peneliti ingin mencoba membuat PTK (Penelitian Tindakan Kelas) dimana peneliti ingin mengembangkan keaktifan siswa dalam keterampilan berbicara dengan menggunakan Games sebagai media pembelajaran. Dengan menggunakan Games dalam pembelajaran Bahasa Inggris diharapkan siswa dapat aktif dalam pembelajaran dan juga dalam keterampilan berbicara. Seperti yang diutarakan oleh Slattery dan Willis (2001:38) bahwa guru dapat mendorong siswa untuk menggunakan bahasa Inggris dengan memainkan suatu permainan dalam waktu yang sama

Martin (dalam Brewster, 2002) mengutarakan salah satu alasan menggunakan games dalam pembelajaran bahasa Inggris yakni dalam games terkandung kegiatan yang menyenangkan yang dapat memberikan siswa kesempatan untuk mempraktekan bahasa 
Inggris yang telah dipelajari dalam rangkaian jalan yang menyenangkan. Alasan lain juga diutarakan oleh Lewis dan Bedson (1999) mengenai penerapan games dalam pembelajaran bahasa Inggris yakni bahwa melalui games siswa dapat bereksperimen, menggali, dan berinteraksi dengan lingkungan. Dengan demikian games juga dapat diartikan sebagai alat yang esensial bagi siswa untuk memahami suatu pengetahuan. Kemudian diperkuat oleh pendapat Ludewig dan Swan (2007-154) melalui penyataan The Power of Games, bahwa games memiliki kekuatan untuk mendorong perhatian siswa dan memotivasi siswa dalam pembelajaran. Permainan atau games tidak lagi semata-mata sesuatu yang hanya dapat dimainkan dan disenangi oleh siswa tetapi dapat bermanfaat pula apabila digunakan atau dimanfaatkan dalam suatu pembelajaran sebagai media pembelajaran. Dalam hal ini yang dibutuhkan adalah kreatifitas guru dalam memodifikasi suatu permainan dalam upaya menyelenggarakan pembelajaran yang bermakna dan menyenangkan bagi siswa. Oleh karena itu, kekuatan yang terkandung dalam games tersebut dapat dimanfaatkan untuk pembelajaran. Sehingga siswa dapat termotivasi dan fokus saat pembelajaran berlangsung.

\section{METODE PENELITIAN}

Jenis penelitian ini adalah Penelitian Tindakan Kelas (PTK). Penelitian dilaksanakan di kelas IX SMPLB Banda Aceh. Subjek penelitian ini adalah siswa - siswi kelas IX SMPLB Banda Aceh yang berjumlah 11 siswa. Objek penelitian ini adalah keseluruhan kegiatan guru dan siswa dalam proses pembelajaran Bahasa Inggris dengan penerapan games sebagai media pembelajaran di kelas IX SMPLB Banda Aceh. Penelitian tindakan kelas ini dilakukan dalam dua siklus tindakan. Tiap siklus terdiri dari 4 tahap yaitu: 1) perencanaan, 2) pelaksanaan, 3) pengamatan, dan 4) refleksi.

\section{HASIL PENELITIAN DAN PEMBAHASAN Siklus I}

Siklus pertama terdiri dari dua pertemuan yang dilaksanakan pada tanggal 2 dan 3 Oktober 2018. Proses pembelajaran pada siklus ini berlangsung selama 2 jam pelajaran yaitu 2 x 40 menit. Adapun rencana kegiatan yang dilakukan pada siklus I meliputi tahap perencanaan, pelaksanaan tindakan, pengamatan, dan refleksi.

\section{Perencanaan}

Pada tahap perencanaan tindakan yang dilakukan pada siklus I, peneliti merancang : RPP (rencana pembelajaran), instrument penilaian siswa, media, lembar observasi untuk mengamati pelaksanaan pembelajaran dengan media games.

\section{Pelaksanaan}

Berdasarkan rencana tindakan dan rencana pembelajaran yang telah dipersiapkan peneliti memulai kegiatan pembelajaran :

Pada kegiatan pendahuluan, guru menyiapkan peserta didik secara fisik dan psikis untuk mengikuti proses pembelajaran dengan memberikan salam, berdoa, melihat ruang lingkup kelas (kerapian, kebersihan), melihat kerapian dari peserta didik dan memeriksa kehadiran peserta didik. Guru memberikan refleksi kepada peserta didik dan dilanjutkan 
Mariah M. Yunus

dengan memotivasi siswa untuk belajar, setelah itu dilanjutkan dengan menanyakan materi minggu lalu dan mengaitkannya dengan materi hari ini. Guru juga menyampaikan tujuan pembelajaran atau kompetensi yang akan dicapai, dimana setelah pembelajaran selesai peserta didik mampu berbahasa Inggris dengan menggunakan materi yang telah dipelajari. Guru memberikan pengarahan tentang proses pembelajaran hari ini, dimana guru menjelaskan kegiatan yang akan dilakukan secara kelompok maupun individual. Penilaian yang meliputi sikap, kognitif maupun psikomotor akan dinilai saat proses pembelajaran berlangsung.

Pada kegiatan inti terdapat 5M (mengamati, menanya, mengumpulkan informasi, mengolah informasi dan mengkomunikasikan) pada kegiatan inti wktunya 70 menit dengan langkah kegiatan meliputi:

Kegiatan observing/mengamati, guru memperlihatkan sebuah video tentang percakapan dua orang yang menceritakan kegiatan mereka yang sedang dilakukan sekarang (present continuous). Guru meminta siswa untuk mengamati video tersebut dan memberikan task kepada peserta didik tentang video dan peserta didik menjawab pertanyaan sesuai dengan video yang sedang diputar.

Kegiatan questioning/bertanya, dalam tahap ini guru memfasilitasi peserta didik untuk menanyakan hal-hal yang belum dipahami dari video yang telah mereka amati dan guru menanyakan hasil jawaban dari pengamatan video.

Kegiatan experimenting/mengumpulkan informasi, guru membagikan worksheet tentang pengunaan kalimat present continuous dan meminta siswa untuk menjawab pertanyaan yang terdapat dalam worksheet tersebut secara individual, karena dalam hal ini, terjadi penilaian untuk perorangan, guru melihat sejauh mana siswa paham tentang materi yang telah di ajarkan.

Kegiatan mengasosiasikan/mengolah informasi, guru membahas hasil jawaban peserta didik bersama-sama sehingga peserta didik tau kesalahan dari jawaban mereka. Pada kegiatan networking/mengkomunikasikan, guru membagikan siswa kepada kelompok, dan memberikan game snake and ladder. Peraturan dalam game ini, siswa diharapakan dapat merangkai kalimat yang terdapat didalam snake and ladder yang telah disiapkan oleh guru. Pada tahap ini, semua siswa di harapkan aktif untuk menjawab pertanyaan yang ada pada snake and ladder.

Pada kegiatan penutup, guru dan peserta didik secara bersama-sama menyimpulkan hal-hal yang telah dipelajari pada pertemuan ini. Guru menjelaskan rencana kegiatan yang akan datang.

\section{Observasi}

Aktivitas peserta didik pada pertemuan siklus I di ukur dengan menggunakan instrument penilaian aktivitas peserta didik yang dilakukan oleh dosen pembimbing, guru pembimbing ataupun teman sejawat. Pada penilaian yang dilakukan oleh pengamat, indikator pencapaian pada siklus I meliputi :

a. Mencari dan memberikan informasi

b. Bertanya kepada guru atau siswa lain

c. Mengajukan pendapat atau komentar kepada guru atau kepada siswa.

d. Dapat bekerja sama dan berhubungan dengan siswa lain 
e. Dapat menjawab pertanyaan guru dengan tepat saat berlangsungnya pembelajaran

f. Aktif dalam permainan yang sedang berlangsung.

g. Termotivasi untuk berbicara saat proses pembelajaran berlangsung

h. Melakukan tugas sesuai dengan instruksi guru.

i. Percaya diri ketika berbicara didepan guru dan siswa.

j. Mendemostrasikan hasil kerja siswa dengan baik dan benar

k. Dapat menjawab pertanyaan yang diberikan oleh guru pada akhir pembelajaran

1. Memberikan refleksi tentang materi yang telah dipelajari

Hasil yang didapatkan dari observasi pada siklus I,76\% dari peserta didik sudah tercapai dalam aspek penilaian aktivitas pembelajaran, dimana siswa antusias dalam proses pembelajaran. $24 \%$ dari peserta didik masih kurang semangat dalam proses pembelajaran.

\section{Refleksi}

Pada tahap refleksi ini, langkah yang di ambil pada siklus I, peneliti menganalisi data yang dikumpulkan, diperoleh dari hasil observasi dan tes kognitif/psikomotor. Hal ini dilakukan untuk menentukan apakah siklus pertama dikategorikan berhasil atau tidak. Dalam hal ini, peneliti dan pengamat melakukan analisis dan refleksi berdasarkan kriteria yang telah ditentukan dalam proses penelitian tindakan kelas. Ada tiga jenis analisis yang dilakukan dalam langkah ini, yaitu:

\section{Analisis Proses Belajar Mengajar}

Analisis proses belajar mengajar terdiri dari evaluasi kinerja guru dalam mengajar keterampilan berbicara dengan menggunakan media games dan kinerja peserta didik dalam belajar keterampilan berbicara dengan penggunaan media games. Berdasarkan hasil observasi untuk guru menunjukkan bahwa kinerja guru dalam proses pembelajaran khususnya pada keterampilan berbicara yang menggunakan media games dapat dikategorikan baik. Selanjutnya hasil observasi pada peserta didik dalam keterampilan berbicara dengan menggunakan games sebagai media, dapat dikategorikan baik. Walaupun ada beberapa siswa yang masih kurang semangat atau kurang percaya diri untuk berbicara selama proses pembelajaran berlangsung.

\section{Analisis Hasil Belajar}

Hasil dari proses pembelajaran dalam siklus I menunjukkan nilai peserta didik sudah mencapai nilai rata-rata KKM, walaupun ada beberapa peserta didik yang masih kurang pencapaian dalam nilai KKM, jadi dapat disimpulkan 76\% siswa dikategorikan sudah memuaskan dalam hasil pembelajaran khususnya dalam keterampilan berbicara dan $24 \%$ siswa dikategorikan belum memuaskan dalam hasil keterampilan berbicara. Dalam hal ini, dapat dikatakan siklus I masih perlu ada perbaikan dalam beberapa aspek dalam proses pembelajaran ataupun media games yang digunakan dapat ditambahkan lagi sehingga peserta didik dapat meningkatkan hasil kinerja belajar.

\section{Analisi Tindakan}


Dalam melaksanakan tindakan kelas dalam siklus I, ada beberapa kelemahan ditemukan selama tindakan. Baik pada guru maupun pada peserta didik. Oleh sebab itu pada siklus II diharapakan ada perubahan yang dilakukan oleh guru sehingga tindakan yang diperbaiki oleh guru dapat menghasilkan kinerja yang baik pada peserta didik.

\section{Hasil Analisis dan Refleksi Siklus I}

Hasil analisis dan refleksi siklus I dapat diuraikan sebagai berikut:

1. Skor kinerja peserta didik dalam proses pembelajaran khususnya dalam keterampilan berbicara dapat dikategorikan baik.

2. Rata-rata skor peserta didik dalam keterampiran berbicara adalah diatas rata-rata nilai KKM, walaupun ada beberapa peserta didik yang masih diantara nilai rata-rata KKM. Peneliti menyimpulkan bahwa siklus I masih kurang berhasil karena ada beberapa peserta didik mendapatkan nilai yang kurang memuaskan.

Dari hasil analisis dan refleksi pada siklus I, peneliti berharap pada siklus II ada perubahan signifikan pada proses belajar mengajar, dan hasil kinerja peserta didik.

\section{Tindak Lanjut}

Tindak lanjut yang diharapakan yaitu melakukan siklus II dalam penelitian tindakan kelas yang dilakukan oleh peneliti. Dalam siklus II ini, peneliti melakukan perencanaan ulang dalam hal RPP, pelaksanaan dalam proses pembelajaran, mengamati peserta didik yang dilakukan oleh guru maupun pengamat dan merefleksikan hasil siklus II. Pada siklus kedua ini, peneliti melakukan dua pertemuan untuk melaksanakan tindakan kelas.

\section{Siklus II}

Kegiatan ini dilaksanakan pada tanggal 9 dan 10 Oktober 2018. Dalam hal ini bagian dari kegiatan peneliti adalah merevisi rencana pembelajaran khususnya dalam keterampilan berbicara melalui media games dan materi pembelajaran. Dalam proses ini, peneliti menggunakan guessing game dalam materi past continuous tense dalam rangka untuk mendapatkan hasil yang memuaskan dalam siklus kedua.

\section{Perencanaan}

Pada siklus II dilakukan dengan tahapan-tahapan seperti siklus I tetapi didahului dengan perencanaan ulang berdasarkan hasil-hasil yang diperoleh pada siklus I (refleksi), sehingga kelemahan yang terjadi pada siklus I tidak terjadi pada siklus II. Dalam langkah ini peneliti mempersiapkan perangkat pembelajaran yang terdiri dari perencanaan dalam proses belajar, soal tes, tes lisan dan media yang dapat menunjang proses yang lebih baik pada siklus kedua.

\section{Pelaksanaan}

Pada siklus II rangkaian pelaksanaan pembelajaran pada pendahuluan sama namun pada kegiatan inti terdapat perbedaan diantaranya adalah sebagai berikut:

Kegiatan observing/mengamati, guru memberikan video tentang kejadian pada masa lampau (past continuous). Dimana ketika ada suatu kejadian terjadi kejadian yang lain didalam waktu yang bersamaan dalam bentuk lampau. Guru meminta siswa untuk 
mengamati video secara berkelompok. Video yang ditampilkan oleh guru di ulang beberapa kali sehingga peserta didik paham dengan video yang diputarkan.

Kegiatan questioning/bertanya, guru memberikan pertanyaan tentang video tersebut. Guru meminta siswa untuk menjawab pertanyaan tersebut sesuai dengan video yang telah ditonton. Setelah menjawab pertanyaan tersebut, guru meminta siswa untuk menulis hasil jawabannya kepapan tulis dan mendiskusikan hasil pengamatan peserta didik. Kemudian guru memfasilitasi peserta didik untuk menanyakan hal-hal yang belum dipahami dari hasil diskusi yang telah dilakukan.

Kegiatan experimenting/mengumpulkan informasi, guru membagikan worksheet tentang pengunaan kalimat past continuous dan meminta siswa untuk menjawab pertanyaan yang terdapat dalam worksheet tersebut secara individual, karena dalam hal ini, terjadi penilaian untuk perorangan, guru melihat sejauh mana siswa paham tentang materi yang telah di ajarkan.

Kegiatan mengasosiasikan/mengolah informasi, guru meminta siswa untuk duduk dengan kelompok yang telah tentukan oleh guru. Pada tahap ini guru memberikan guessing game, dimana peserta didik diberikan sebuah kasus tentang kriminalitas. Peserta didik diminta untuk membuat ide yang menarik dalam membuat alibi yang membinggungkan sehingga ketika peserta didik yang lain menebak pelaku dalam kasus kriminal tersebut mendapatkan kesulitan untuk menentukan siapa tersangka dalam kasus tersebut. Dalam hal ini peserta didik dalam kelompoknya harus melakukan kerja sama dan saling membantu untuk dapat menghasilkan alibi yang baik.

Kegiatan networking/mengkomunikasikan, guru meminta peserta didik untuk mempresentasikan dalam bentuk drama mini kepada peserta didik lainnya tenang kasus mereka. Pada proses ini setiap yang tampil membacakan alibi yang berbeda-beda pada kasus mereka, dan peserta didik yang lainnya mendengarkan alibi tersebut dan menjawab siapakah tersangka dalam kasus yang ditampilkan oleh teman mereka. Pada guessing game ini terdapat satu kelompok yang memiliki alibi yang membinggungkan sehingga kelompok yang lainnya tidak dapat menebak tersangka dari kasus mereka. Kelompok tersebut dinyatakan menang dalam permainan guessing game.

Pada kegiatan penutup, guru dan peserta didik secara bersama-sama menyimpulkan hal-hal yang telah dipelajari pada pertemuan ini. Guru menjelaskan rencana kegiatan yang akan datang, siklus II ini dilaksanakan dua kali pertemuan dengan alokasi waktu 2x40 menit.

\section{Observasi}

Pengamatan yang dilaksanakan pada siklus II menggunakan indikator yang sama dengan siklus I. Dalam hal ini, persentase penilaian aktivitas peserta didik meningkat lebih baik. Terjadi perubahan yang signifikan terhadap peserta didik, dimana mereka menjadi lebih antusias dan semangat dalam proses pembelajaran berlangsung.

\section{Refleksi}

Pada tahap refleksi ini, langkah yang di ambil pada siklus II, peneliti menganalisi data yang dikumpulkan, yang diperoleh dari hasil observasi dan tes kognitif/psikomotor. 
Mariah M. Yunus

Hal ini dilakukan untuk menentukan apakah siklus kedua dikategorikan berhasil atau tidak. Dalam hai ini, peneliti dan pengamat melakukan analisis dan refleksi berdasarkan kriteria yang telah ditentukan dalam proses penelitian tindakan kelas. Ada tiga jenis analisis yang dilakukan dalam langkah ini, yaitu:

\section{Analisis Proses Belajar dan Mengajar}

Analisis proses belajar mengajar terdiri dari evaluasi kinerja guru dalam mengajar keterampilan berbicara dengan menggunakan media games dan kinerja peserta didik dalam belajar keterampilan berbicara dengan penggunaan media games. Berdasarkan hasil observasi untuk guru menunjukkan bahwa kinerja guru dalam siklus kedua ini pada proses pembelajaran khususnya keterampilan berbicara yang menggunakan media games dapat dikategorikan sangat baik, karena guru memberikan permainan baru yang lebih menantang dari permainan sebelumnya. Selanjutnya hasil observasi pada peserta didik dalam keterampilan berbicara dengan menggunakan games sebagai media, dapat dikategorikan sangat baik dan memuaskan karena peserta didik menunjukkan keaktifan mereka dalam proses memainkan permainan.

Dapat disimpulkan bahwa proses belajar dan mengajar pada siklus kedua ini memperoleh peningkatan yang sangat baik jadi siklus kedua dalam tindakan kelas di nyatakan berhasil menigkatkan keaktifan dan semangat siswa dalam kelas melalui media games pada keterampilan berbicara.

\section{Analisis Hasil Belajar}

Dalam siklus II, hasil dari proses pembelajaran menunjukkan nilai peserta didik sudah mencapai di atas rata-rata nilai KKM. 86\% siswa dikategorikan berhasil dalam proses pembelajaran khususnya dalam keterampilan berbicara. Dalam hal ini, dapat dikatakan siklus II telah berhasil dimana peserta didik lebih aktif dan termotivasi untuk semangat dalam melaksanakan proses belajar mengajar. Jumlah persentasi peserta didik tersebut telah menunjukkan bahwa ketuntasan nilai pada penilaian indikator telah keberhasilan.

\section{Analisis Aksi}

Dalam pelaksanaan tindakan kelas dalam siklus II, ada beberapa solusi dan pertimbangan yang diambil dalam merespon kelemahan yang ditemukan selama tindakan yang dilakukan pada siklus I. Dalam siklus kedua ini, guru menyiapkan media yang lebih menarik dan permainan yang membuat peserta didik lebih aktif walaupun ada beberapa siswa melakukan kesalahan dalam proses pembelajaran, namun guru tetap melanjutkan proses belajar sehingga peserta didik tidak takut untuk melakukan kesalahan, karena diakhir pertemuan guru memperbaiki kesalahan yang dilakukan oleh peserta didik. Peserta didik dalam siklus kedua ini menunjukkan keaktifan yang signifikan, karena penggunaan media games dalam proses pembelajaran meningkatkan keaktifan mereka dalam keterampilan berbicara.

\section{Hasil Analisis dan Refleksi Siklus II}

Hasil analisis dan refleksi siklus II dapat diuraikan sebagai berikut: 
1. Skor kinerja peserta didik dalam proses pembelajaran khususnya dalam keterampilan berbicara dapat dikategorikan sangat baik/memuaskan.

2. Rata-rata skor peserta didik dalam keterampiran berbicara adalah diatas rata-rata nilai KKM, peneliti menyimpulkan bahwa siklus II berhasil karena peserta didik menunjukkan perubahan yang signifikan dalam siklus ini.

Dari hasil analisis dan refleksi pada siklus II, peneliti merasa puas dengan hasil kinerja yang dilakukan karena ada perubahan yang terjadi pada peserta didik.

\section{Tindak Lanjut}

Berdasarkan hasil pengamatan dan analisis data yang diperoleh guru dan pengamat pada siklus II, telah terlihat adanya peningkatan tindakan guru selama kegiatan pembelajaran berlangsung. Peningkatan dari tindakan yang diberikan guru dapat dilihat dari keberhasilan yang telah dicapai pada siklus II. Pembelajaran yang menggunakan media games yang diterapkan pada siklus II sudah efektif, hal ini terlihat dari peningkatan hasil belajar peserta didik yang sudah mencapai ketuntasan secara signifikan. Persentase yang diperoleh adalah sebesar $86 \%$. Berdasarkan hasil analisis dan refleksi yang dilakukan dalam siklus kedua, peneliti menyimpulkan bahwa siklus kedua telah berhasil karena indikator kriteria keberhasilan menunjukkan nilai keberhasilan yang sangat baik. Hasil tersebut menyakinkan peneliti bahwa siklus II tidak perlu dilanjutkan pada siklus selanjutnya. Dan penelitian tindakan kelas pada kelas IX dicukupkan pada siklus II.

\section{PENUTUP \\ Simpulan}

Dari seluruh rangkaian tindakan yang dilakukan pada Siklus I dan Siklus II, ternyata memberikan hasil yang sangat baik terhadap siswa kelas IX dalam tujuan pembelajaran Bahasa Inggris untuk meningkatkan keterampilan berbicara dengan menggunakan media games dalam proses pembelajaran.

Ternyata dari hasil penelitian yang diperoleh dari kelas IX menunjukkan bahwa penggunaan media games sangat berpengaruh positif bagi peserta didik. Media games yang menarik akan membuat peserta didik tertarik untuk mencoba memainkan permainan tersebut hingga menjadi pemenang dalam permaian tersebut. Begitu peserta didik tertarik dan merasa senang untuk berbicara, maka mereka lupa bahwa sebelumnya (pada kondisi awal sebelum penggunaan media) mereka merasa tidak antusias bahkan merasa tidak semangat dan kurang percaya diri karena tidak berani untuk berbicara. Pemanfaatan media games pada peserta didik terbukti dapat membangkitkan keaktifan dan motivasi mereka untuk mampu berbicara dalam berbahasa Inggris. Karena media games yang menarik bisa memberikan siswa inspirasi ide-ide baru serta penggunaan kosakatanya terkait dengan games yang dimainkan.

Saat pelaksanaan tindakan (Siklus I dan Siklus II) berlangsung tidak ada peserta didik yang mengeluh ketika diminta untuk berbicara, hal itu menunjukkan bahwa pemanfaatan media games mampu menambah rasa percaya diri siswa bahwa mereka mampu untuk menguasai keterampilan berbicara (speaking) dengan baik. 
Mariah M. Yunus

Berdasarkan kajian teori dan kerangka berfikir lalu diikuti hipotesa yang diajukan oleh peneliti, serta hasil penelitian yang dilakukan pada siswa kelas IX, dapat disimpulkan bahwa dengan memanfaatkan media games dapat meningkatkan keterampilan berbicara dalam berbahasa Inggris. Diharapkan kedepan, guru - guru dapat menggunakan media games pada proses pembelajaran sehingga pembelajaran Bahasa Inggris akan menyenangkan terhadap peserta didik disekolah.

\section{DAFTAR PUSTAKA}

Brewster, J., Ellis, G. \& Girard, D. 2002. The primary english teacher's guide. London: Penguin Longman Publishing.

Harmer ,Jeremy. 2001. The Practice of English Language Teaching. London: Longman.

Lewis, Gordon and Günther Bedson. Games for children. Oxford University Press. Oxford, 1999. ISBN 0194372243

Ludewig, A. \& Swan, A. 2007. 101 Great classroom games. New York: McGraw-Hill Companies.

Shastri, P. D. 2010. Communicative approach to the teaching of English as a second language. Mumbai : Himalaya Publishing House.

Slattery, M. \& Willis, J. 2001. English for primary teachers. New York: Oxford University Press

Supriyadi, dkk. 2005. Pendidikan Bahasa Indonesia 2. Jakarta: Depdikbud. 